\title{
Efficacy of Prephase Treatment for the Prevention of Tumor Lysis Syndrome in Lymphoma Cases with High Tumor Burden: A Cross-Sectional Study
}

\author{
Ali OGUL ${ }^{1}$, Semra PAYDAS ${ }^{2}$, Mahmut BUYUKSIMSEK ${ }^{1}$, Abdullah Evren YETISIR ${ }^{3}$ \\ ${ }^{1}$ Adana City Training and Research Hospital, Department of Medical Oncology, Adana \\ ${ }^{2}$ Cukurova University Faculty of Medicine, Department of Medical Oncology, Adana \\ ${ }^{3}$ Sanliurfa Mehmet Akif Inan Training and Research Hospital, Department of Medical Oncology, Sanliurfa,TURKEY
}

\begin{abstract}
This study was conducted to investigate the efficacy of pre-phase therapy in preventing tumor lysis syndrome (TLS) in cases with high tumor burden. This study involved 42 lymphoma patients with moderate to high risk of developing TLS. All of the cases underwent a prephase treatment which consisted of $1 \mathrm{mg}$ of vincristine first day and $100 \mathrm{mg} /$ day of prednisolone for seven days. Afterwards, planned conventional chemotherapy regimens were given. The development of laboratory TLS was evaluated by the end of the conventional cytotoxic treatment. Among the patients, $85.6 \%$ had B cell neoplasia and 14,4\% had T cell lymphoblastic lymphoma (TCLL). The risk of TLS was high in $57.2 \%$ of the cases and intermediate in $42.8 \%$. A total of $42.8 \%$ cases developed laboratory TLS after conventional treatment following prephase therapy. On the other hand, there were $7.1 \%$ patients who exceeded the normal laboratory value limits. In addition, $2.3 \%$ of the cases had only clinical findings of TLS. Treatment response was complete in $57.1 \%$ and partial in $40.5 \%$ with respect to the findings of PET-CT. Prephase therapy may decrease the severity of TLS in cases with a high tumor burden. Prephase therapy may be used in the initial phase in cases at moderate-to-high risk for TLS.
\end{abstract}

Keywords: Lymphoma, Prephase treatment, Tumor lysis syndrome

\section{ÖZET}

Yüksek Tümör Yükü Olan Lenfoma Olgularında Tümör Lizis Sendromunun Önlenmesi için Ön Faz Tedavinin Etkinliği: Kesitsel bir Çalışma

Bu çalışma, tümör yükü yüksek olan olgularda tümör lizis sendromunun (TLS) önlenmesinde faz öncesi tedavinin etkinliğini araştırmak amacıyla yapılmıştır. Bu çalışma, orta ve yüksek TLS gelişme riski olan 42 lenfoma hastasını kapsamaktadır. Tüm olgulara ilk gün 1 mg vinkristin ve yedi gün boyunca 100 mg/gün prednizolondan oluşan bir ön faz tedavisi uygulandı. Daha sonra planlanmış geleneksel kemoterapi rejimleri verildi. Laboratuvar TLS'nin gelişimi konvansiyonel sitotoksik tedavinin sonunda değerlendirildi. Hastaların \%85.6'sında B hücreli neoplazi ve \%14.4'ünde Thücreli lenfoblastik lenfoma (TCLL) vardı. Vakaların \%57.2'sinde yüksek ve \%42.8'inde orta derecede TLS riski vardı. Toplam \%42.8 vakada ön faz tedavisini takiben geleneksel tedaviden sonra laboratuvar TLS gelişti. Öte yandan, normal laboratuvar değer sınılarını aşan \%7.1 hasta vardı. Ek olarak, vakaların sadece \%2.3'ünde TLS klinik bulguları vardı. PET-BT bulgularına göre $\% 57.1$ 'inde tam yanıt ve $\% 40.5$ 'inde kısmi yanıt vardı. Ön faz tedavisi yüksek tümör yükü olan olgularda TLS'nin şiddetini azaltabilir. TLS için orta ila yüksek riskli vakalarda ön fazı tedavisi başlangıç aşamasında kullanılabilir.

Anahtar Kelimeler: Lenfoma, Ön faz tedavisi, Tümör lizis sendromu 


\section{INTRODUCTION}

Tumor lysis syndrome (TLS) is characterized with a rapid lysis of cancer cells and release of intracellular contents including potassium, phosphorus, and uric acid resulting in hyperkalemia, hyperphosphatemia, hypocalcemia, hyperuricemia, and acute renal failure. ${ }^{1}$ While TLS generally occurs after systemic chemotherapy, it may even emerge spontaneously in cases with high tumor burden and/or high proliferative activity. ${ }^{2-4}$ The laboratory TLS has been defined by Cairo-Bishop to have at least two criteria among calcium level falling below the laboratory lower limit or decreasing $25 \%$ and potassium, phosphorus and uric acid levels exceeding the laboratory upper limit or increasing by $25 \%$. In addition to laboratory TLS, having at least one of acute kidney injury (AKI), cardiac arrhythmia and seizure, tetanic or other symptomatic hypocalcemia clinics is sufficient for clinical TLS (Table 1). ${ }^{5,6}$ Risk factors for TLS include decreased urine output, hyperuricemia, renal dysfunction, dehydration, and acidic urine output. ${ }^{7,8}$ Tumor lysis syndrome is an oncologic emergency and associated with high rates of morbidity and mortality. The most important factors in the management of TLS are administration of prophylactic measures and identification of risk groups. ${ }^{9-11}$ Hydration, rasburicase, allopurinol, and febuxostat are used as effective preventive treatments. ${ }^{5}$ However, it can sometimes be insufficient in patients with high tumor burden. Prephase treatment regimen is a regimen that contains a lower dose of single agent cytotoxic agent and corticosteroid than traditional chemotherapy regimens. ${ }^{12}$ The main purpose of prephase therapy is to reduce tumor burden in hematopoietic malignant diseases. In this way, possible side ef- fects may occur with the use of traditional treatment regimens can be reduced. ${ }^{13}$ However, there is not enough study about the effectiveness of prephase treatment in preventing tumor lysis syndrome. In the present study, we aimed to report the outcomes of cases with lymphoma at moderate and high risk for TLS who underwent prephase therapy before standard chemotherapy.

\section{PATIENTS AND METHODS}

A total of 42 cases diagnosed as non-hodgkin lymphoma according to World Health Organization classification of tumors of haematopoietic and lymphoid tissues (revised 4th ed.-2017) between November 2015 and December 2019 were included in this retrospective cross-sectional study.. Patients newly diagnosed with stage II-IV, B cell and $\mathrm{T}$ cell lymphoma older than 18 years of age with a risk of developing moderate and high TLS were included. (Table 2). Patients with stage I disease, prior history of other malignancy, low risk of TLS development, primary CNS lymphoma and diagnosis of HIV-related lymphoma were excluded. Age, sex, lymphoma subtype, B symptoms, Ki-67 score, beta-2 microglobulin, LDH level, national comprehensive cancer network-international prognostic index (NCCN-IPI) score, stage, bulky disease (maximal transverse diameter of $>10 \mathrm{~cm}$ ) and extranodal involvement status were recorded and the risk of TLS was determined according to the Cairo and Coiffier risk classification. ${ }^{14}$ All cases had normal renal function before treatment. All of the cases underwent a prephase treatment which consisted of $1 \mathrm{mg}$ of vincristine first day and $100 \mathrm{mg} /$ day of prednisolone for seven days. Standard TLS proph-

\begin{tabular}{|lll|}
\hline \multicolumn{2}{|l|}{ Table 1. Cairo-Bishop definition of tumor lysis syndrome } & \\
\hline Element & Value & Change from baseline \\
\hline Uric acid & $\geq 476 \mathrm{micromol} / \mathrm{L}(8 \mathrm{mg} / \mathrm{dL})$ & $25 \%$ increase \\
Calcium & $\leq 1.75 \mathrm{mmol} / \mathrm{L}(7 \mathrm{mg} / \mathrm{dL})$ & $25 \%$ decrease \\
Potassium & $\geq 6.0 \mathrm{mmol} / \mathrm{L}(\mathrm{or} 6 \mathrm{mEq} / \mathrm{L})$ & $25 \%$ increase \\
Phosphorus & $\geq 2.1 \mathrm{mmol} / \mathrm{L}(6.5 \mathrm{mg} / \mathrm{dL})$ for children or & $25 \%$ increase \\
& $\geq 1.45 \mathrm{mmol} / \mathrm{L}(4.5 \mathrm{mg} / \mathrm{dL})$ for adults & \\
\hline *Laboratory TLS (tumor lysis syndrome) is two or more laboratory changes within three days before or seven days after cytotoxic therapy. In addition \\
to laboratory TLS, acute kidney injury (AKI), cardiac arrhythmia, and seizure, tetany or other symptomatic hypocalcemia are defined as essential criteria \\
for clinical TLS.
\end{tabular}




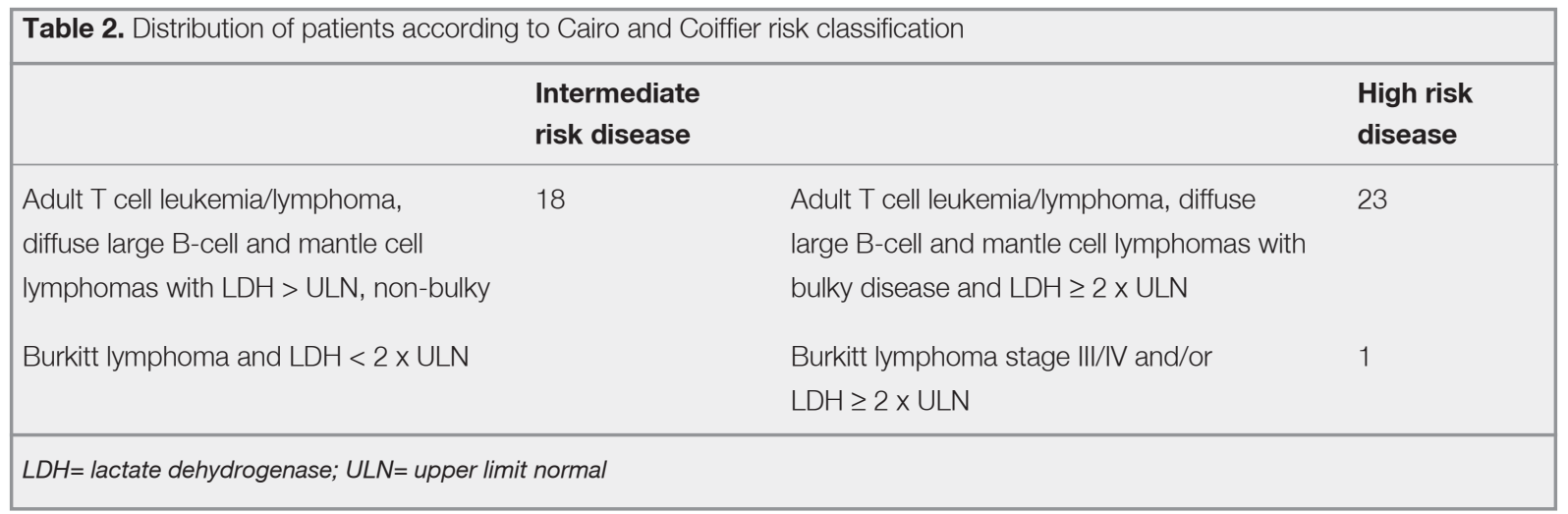

ylaxis including hydration and allopurinol were administered to the cases during the treatment period. All of the cases with DLBCL cell lymphoma received R-CHOP (rituximab-cyclophosphamide, doxorubicin, vincristine and prednisone) regimen and hyper-CVAD/Mtx-ARA-C (cyclophosfamide, vincristine, doxorubicin, dexamethasone, methotrexate, cytarabine) regimen were administered to cases with Burkit lymphoma and mantle cell lymphoma with the p53 mutation. Cases diagnosed with peripheral T-cell lymphoma were given hyper-CVAD/Mtx-ARA-C and CHOEP (cyclophosphamide, doxorubicin, vincristine, etoposide and prednisone) treatment regimens. The case diagnosed with adult T-cell lymphoma received hyper-CVAD/Mtx-ARA-C regimen. Uric acid, blood urea nitrogen (BUN), creatinine, phosphorus, calcium, potassium, and lactate dehydrogenase (LDH) levels were monitored regularly. Standard chemotherapy was administered the day after the end of treatment prephase treatment. The patients were evaluated for TLS development after the conventional treatment regimen. All cases were evaluated with interim PET-CT after the second cycle of treatment. Treatment responses were evaluated using the PET-CT based Lugano response criteria. ${ }^{15}$

\section{Statistical Analysis}

Statistical analysis was performed using the statistical package SPSS software (Version 25.0, SPSS Inc., Chicago, IL, USA). For each continuous variable, normality was checked by Kolmogorov Smirnov and Shapiro-Wilk tests and by histograms. All numerical data are expressed as mean values or as proportions. Comparisons between pre-post measures were applied using Wilcoxson test was used for the data not normally distrubited. Values of $\mathrm{p}<0.05$ were considered statistically.

\section{Ethical Approval}

All procedures performed in studies involving human participants were in accordance with the ethical standards of the institutional and/or national research committee and with the 1964 Helsinki Declaration and its later amendments or comparable ethical standards. The study was approved by the Adana City Education and Research Hospital Clinical Research Ethics Committee (Date: December 18, 2019/ No: 649). Informed consent was obtained from all cases for being included in the study. Informed consent form was taken from the patient with the picture.

\section{RESULTS}

The mean age of the cases was $61.2 \pm 17$ and $50 \%$ were males. Of 42 cases, $85.6 \%$ had B cell and $14.4 \%$ had $\mathrm{T}$ cell lymphoma (excluding lymphoblastic leukemia) and $85.7 \%$ presented with $\mathrm{B}$ symptoms. Mean Ki67 score was $73 \% \pm 18$ and the mean beta 2 microglobulin level was $5.22 \pm 3.2$ in cases. The LDH level $78.6 \%$ of the patients was more than twice the normal upper limit. $81 \%$ cases had diffuse large B cell lymphoma (DLBCL), $2.3 \%$ case had Burkitt's lymphoma (BL) and 2.3\% case mantle cell lymphoma (MCL). $57.2 \%$ cases had high and $42.8 \%$ had intermediate risk of TLS 


\begin{tabular}{|c|c|c|c|c|c|}
\hline & No & $\%$ & & No & $\%$ \\
\hline Age (year) & & & TLS risk & & \\
\hline$<60$ & 22 & 52.4 & Intermediate & 18 & 42.8 \\
\hline$\geq 60$ & 20 & 47.6 & High & 24 & 57.2 \\
\hline Gender & & & Ekstranodal involvement & & \\
\hline Male & 21 & 50 & Yes & 8 & 19 \\
\hline Female & 21 & 50 & No & 34 & 81 \\
\hline NCCN-IPI & & & B cell lymphoma & & \\
\hline$\leq 3$ & 17 & 40.5 & DLBCL & 34 & 81 \\
\hline$\geq 4$ & 25 & 59.5 & Burkitt lymphoma & 1 & 2.3 \\
\hline B symptoms & & & Mantle cell lymphoma & 1 & 2.3 \\
\hline Yes & 36 & 85.7 & T cell lymphoma & & \\
\hline No & 6 & 14.3 & Peripheral T-cell lymphoma & 5 & 12,1 \\
\hline Ki67 (\%) & & & Adult T-cell lymphoma & 1 & 2.3 \\
\hline$<70$ & 11 & 35.5 & & & \\
\hline$\geq 70$ & 31 & 64.5 & LaboratPry TLS & 18 & 42.8 \\
\hline LDH & & & Clinical TLS & 1 & 2.3 \\
\hline$\geq 2 X U L N$ & 33 & 78.6 & Response rates & & \\
\hline Bulky disease & 23 & 54.8 & & & \\
\hline Stage & & & Partial response & 17 & 40.5 \\
\hline$\|-1\|$ & 10 & 23.8 & Complete response & 24 & 57.1 \\
\hline IV & 32 & 76.2 & No response & 1 & 2.3 \\
\hline
\end{tabular}

with respect to the Cario and Coiffier risk scores. Table 3 shows the characteristics of the cases. The mean LDH levels were $692 \pm 542$ and $345 \pm 198$, respectively before and after prephase therapy $(\mathrm{p}=$ 0.0002). According to the laboratory values at the end of prephase treatment, no elevation was detected except for uric acid elevation on the first day after conventional chemotherapy (Figure 1-2). According to the Cairo-Bishop TLS criteria, TLS was detected in $42.8 \%$ cases after seven days of follow up from the end of conventional therapy. On the other hand, there were $7.1 \%$ patients who exceeded the normal laboratory value limits. None of the cases except one developed clinical TLS. This case had a grade II increase in creatinine and AKI resolved after medical treatment. After two cycles of conventional chemotherapy PET-CT was studied and $57.1 \%$ cases had a complete response and $40.5 \%$ cases had a partial response while $2.3 \%$ case did not respond to treatment.

\section{DISCUSSION}

Tumor lysis syndrome is an oncologic emergency and prophylaxis is the most effective preventive treatment. The incidence of TLS is variable with respect to tumor burden, proliferative activity, and chemosensitivity. ${ }^{2}$ The most common causes of TLS are acute lymphoblastic leukemia (ALL) and high grade lymphomas especially Burkitt's lymphoma. ${ }^{9}$ In a retrospective study involving 102 cases with high grade lymphomas, TLS has been reported in $42 \%$ of the cases, however clinically meaningful TLS was present in $6 \%$ of the cases. ${ }^{9}$ The incidence of clinic TLS has been reported as high as $25 \%$ in cases with precursor B-ALL and Burkitt's lymphoma. ${ }^{16-18}$ Complications associated with TLS increase the rates of morbidity and mortality. ${ }^{19-21}$ For this reason, following precautions is the most important measure in the management of these neoplasms. Hydration, allopurinol, and close monitoring of the cases are essential points. In the 


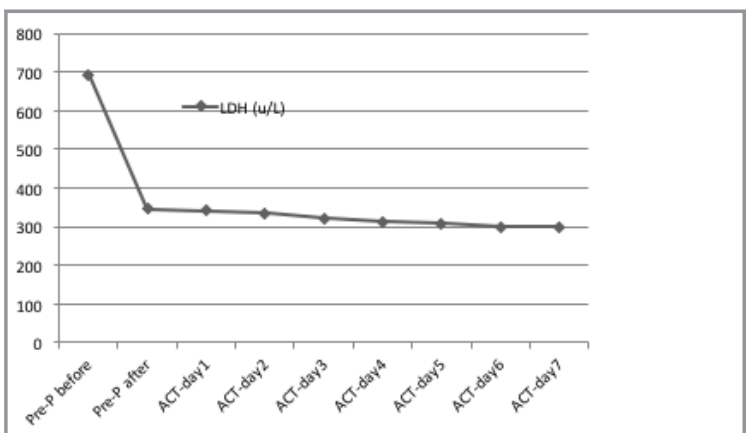

Figure 1. $\mathrm{LDH}$ levels of patients before and after pre-phase therapy and after conventional therapy

Pre- $P=$ Pre-phase treatment; $A C T=$ After conventional therapy

present study, laboratory TLS developed in $42.8 \%$ of the cases, however with respect to the criteria regarding the upper limits of laboratory values, it developed in only $7.1 \%$ of the cases. The main aim of prephase therapy in cases with high tumor burden and/or high proliferative rate is to facilitate controlled tumor destruction and to ensure a lower tumor bulk before the administration of conventional chemotherapy and also to decrease the risk of TLS. This is supported by the pre-and post-treatment clinical picture of the case with breast- lymphoma in our study. This case had a tumor mass which involved the nipple and the tumor mass substantially regressed just after the administration of prephase therapy (Figure 3). The fact that no other case developed clinical TLS during conventional treatment implies that the administration of pre-

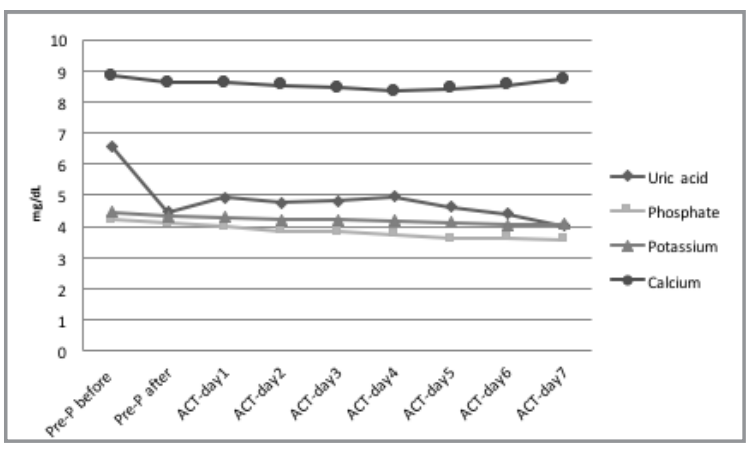

Figure 2. The mean Uric acid, phosphate, potassium and calcium levels of patients before and after pre-phase therapy and after conventional therapy

Pre $-P=$ Pre-phase treatment; $A C T=$ After conventional therapy

phase treatment may be protective against clinical TLS. To the best of our knowledge, there are no large-scale or controlled studies about the use of prephase therapy. In a study by Cui et al. ${ }^{19}$ involving 54 gastric lymphoma cases,, low dose prephase therapy before conventional treatment was associated with a higher complete response rate and a lower risk of gastrointestinal perforation as compared with conventional chemotherapy alone. Although the response rate in the present study was similar with that seen after conventional treatment in cases with NHL, the net effect of prephase therapy on the treatment response rate is not known. Also the effect of prephase therapy on disease free survival, overall survival, morbidity, and mortality are not clear. ${ }^{22}$ Although the standard approach to avoid TLS (hydration, allopurinol, rasburicase, fe-

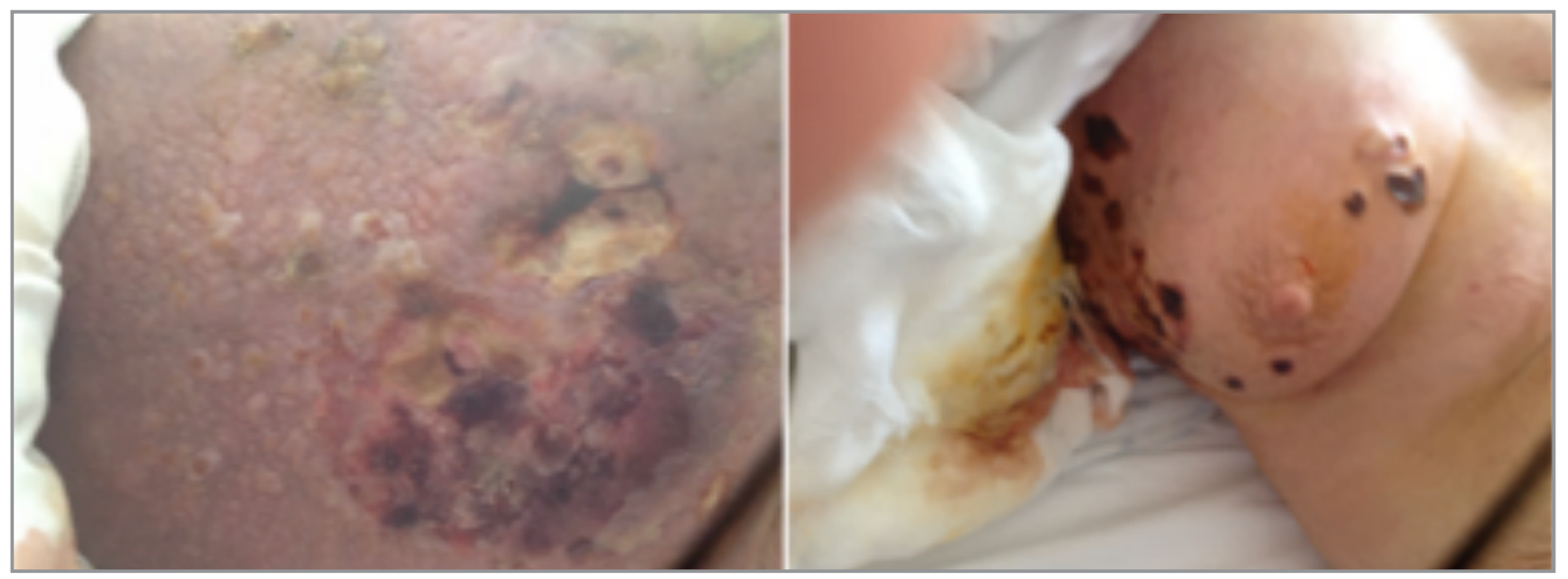

Figure 3. The images of the patient with breast-lymphoma involvement before and after pre-phase treatment 
buxostat, etc.) are the initial choice of most clinicians, the rate of clinical TLS remains to be around $6 \%$. Because rasburicase and febuxostat are not available in our country, allopurinol was used in cases at risk for TLS instead of these two agents more potent. However, the risk of laboratory TLS was low and the risk of clinical TLS was even lower and clinical response rates were unchanged. Although many clinicians desire to initiate conventional treatment in cases with NHL, administration of prephase before conventional treatment seems benefical for cases at moderateto-high risk for TLS because it reduces the rate of clinical TLS without influencing treatment response.

The main limitation of the study was that it consisted of single-center, retrospective and relatively few patients. In addition, the fact that prephase treatment effects on disease-free survival and overall survival were not studied was another limitation.

\section{Conclusion}

Prephase therapy may decrease the severity of TLS in cases with a high tumor burden. In this respect, complications arising from TLS and treatment delays may be avoided and the response rate to treatment can be maintained acceptable. We suggest that, prephase therapy may be used in the initial phase in cases at moderate-to-high risk for TLS in locations where access to rasburicase and febuxostat is not possible.

\section{Acknowledgement}

This study received the best paper award at $\mathrm{Na}$ tional Immunotherapy and Oncology Congress in Turkey in 25-29 September 2017.

\section{REFERENCES}

1. Wechsler DS, Kastan MB, Fivush BA. Resolution of nephrocalcinosis associated with tumor lysis syndrome. Pediatr $\mathrm{He}-$ matol Oncol 11: 115-118, 1994.

2. Tannock I. Cell kinetics and chemotherapy: a critical review. Cancer Treat Rep 62: 1117-1133, 1978.

3. Seegmiller JE, Laster L, Howell RR. Biochemistry of uric acid and its relationship to gout. N Engl J Med 268: 712-716, 1963.
4. Van den Berghe G. Purine and pyrimidine metabolism between millennia: what has been accomplished, what has to be done? Adv Exp Med Biol 486: 1-4, 2000

5. Cairo MS, Bishop M. Tumour lysis syndrome: new therapeutic strategies and classification. $\mathrm{Br} J$ Haematol 127: 3-11, 2004.

6. Rampello E, Fricia T, Malaguarnera M. The management of tumor lysis syndrome. Nat Clin Pract Oncol 3: 438-447, 2006.

7. Frei El, Bentzel CJ, Rieselbach R, Block JB. Renal complications of neoplastic disease. J Chronic Dis 16: 757-776, 1963.

8. Tsokos GC, Balow JE, Spiegel RJ \& Magrath IT. Renal and metabolic complications of undifferentiated and lymphoblastic lymphomas. Medicine 60: 218-229, 1981.

9. Hande KR, Garrow GC. Acute tumor lysis syndrome in patients with high-grade non-Hodgkin's lymphoma. Am J Med 94: 133-139, 1993.

10. Bishop MR, Coccia PF. Tumor lysis syndrome. In: Clinical Oncology (ed. by Abeloff MD, Niederhuber JE, Armitage JO, Lichter AS), Churchill Livingstone, New York, 2000: 750-754.

11. Mughal TI, Ejaz AA, Foringer JR, et al. An integrated clinical approach for the identification, prevention, and treatment of tumor lysis syndrome. Cancer Treat Rev 36: 164-176, 2010.

12. Lakshmaiah KC, Asati V, Babu KG, et al. Role of prephase treatment prior to definitive chemotherapy in patients with diffuse large B-cell lymphoma. Eur J Haematol 100: 644-648, 2018.

13. Malpica L, Galeotti J, Grover N, et al. A retrospective study on prephase therapy prior to definitive multiagent chemotherapy in aggressive lymphomas. Leuk Lymphoma Feb 9;1-4, 2020. doi: 10.1080/10428194.2020.1725505. (Ahead of print)

14. Cairo MS, Coiffier B, Reiter A, et al. Recommendations for the evaluation of risk and prophylaxis of tumour lysis syndrome (TLS) in adults and children with malignant diseases: an expert TLS panel consensus. Br J Haematol 149: 578-586, 2010.

15. Barrington SF, Mikhaeel NG, Kostakoglu L, et al. Role of imaging in the staging and response assessment of lymphoma: consensus of the International Conference on Malignant Lymphomas Imaging Working Group. J Clin Oncol 32: 30483058, 2014

16. Montesinos P, Lorenzo I, Martin G, et al. Tumor lysis syndrome in patients with acute myeloid leukemia: identification of risk factors and development of a predictive model. Haematologica 93: 67-74, 2008.

17. Wossmann W, Schrappe M, Meyer U, et al. Incidence of tumor lysis syndrome in children with advanced stage Burkitt's lymphoma/ leukemia before and after introduction of prophylactic use of urate oxidase. Ann Hematol 82: 160-165, 2003.

18. Stapleton FB, Strother DR, Roy III S, et al. Acute renal failure at onset of therapy for advanced stage Burkitt lymphoma and B cell acute lymphoblastic Iymphoma. Pediatrics 82: 863869, 1988. 
19. Levine, AM. Challenges in the management of Burkitt's lymphoma. Clin Lymphoma 3 Suppl 1: 19-25, 2002.

20. Yim, BT, Sims-McCallum RP, Chong PH. Rasburicase for the treatment and prevention of hyperuricemia. Ann Pharmacother 37: 1047-1054, 2003.

21. Hsu HH, Chan YL, Huang CC. Acute spontaneous tumor lysis presenting with hyperuricemic acute renal failure: Clinical features and therapeutic approach. J Nephrol 17, 50-56, 2004.

22. Cui Y, Li X, Sun Z, et al. Safety and efficacy of low-dose prephase before conventional-dose chemotherapy for ulcerative gastric diffuse large B-cell lymphoma. Leuk Lymphoma 56: 2613-2618, 2015.

\section{Correspondence:}

Dr. Ali OGUL

Adana Sehir Egitim ve Arastirma Hastanesi

Tibbi Onkoloji Bölümü

Yüregir 01060, ADANA / TURKEY

Tel: (+90-552) 2546485

e-mail: mdaliogul@gmail.com

\section{ORCIDs:}

Ali Oğul:

0000-0003-4886-7060

Semra Paydaş: $\quad$ 0000-0003-4642-3693

Mahmut Büyükşimsek: 0000-0001-6356-9059

Abdullah Evren Yetişir: 0000-0001-7214-8184 